\section{Received}

Feb, $27^{\text {th }} 2021$
Accepted

Jun, 24 2021
Published

Jun, 27 2021

\title{
Human Dignity in the Counseling Perspective
}

\author{
Andika Fawri \\ Universitas Negeri Padang, West Sumatra, Indonesia \\ *E-mail: andikafawri2018@gmail.com
}

\begin{abstract}
Human dignity is a human nobility that distinguishes it from other creatures on earth. The purpose of writing this article is to describe human dignity in the perspective of counseling. The method used in this writing is literature study. The data collection technique in this article is the documentation technique. The data analysis technique used is content analysis technique. Based on the results of the author's search, humans are not born in an empty state where humans are given a noble spirit by God, the proof of which is the Qur'an as in its content, humans are created in the best possible shape and perfect. Human dignity is influenced by the conditions chosen by the human being, but if it is taken from the word nobility, humans must do and become a better person.
\end{abstract}

Keywords: Counseling; Human Dignity; Perspective.

\begin{abstract}
Abstrak
Harkat martabat manusia merupakan keluhuran manusia yang membedakan dari mahkluk-mahluk lain dibumi. Tujuan penulisan artikel ini adalah untuk mengurai tentang harkat martabat manusia dalam perspektif konseling. Metode yang digunakan dalam penulisan ini adalah studi kepustakaan. Teknik pengumpulan data pada artikel ini yaitu teknik dokumentasi. Teknik analisis data yang digunakan adalah teknik analisis isi. Berdaarkan hasil penelusuran penulis, manusia lahir memang bukan dalam keadaan kosong yang mana mausia diberikan ruh yang mulia oleh tuhan yang mana buktinya adalah Al-quran sebagaimana kandungannya manusia diciptakan sebaik baiknya bentuk dan sesempurna mungkin. Harkat martabat manusia di pengaruhi oleh kondisi yang di pilih manusia tersebut namun jika di ambil dari kata keluhuran manusia haruslah melakukan dan menjadi pribadi yang lebih baik.
\end{abstract}

Kata Kunci: Konseling; Harkat Martabat Manusia; Perspektif.

\section{PENDAHULUAN}

Berdasarkan Undang-undang republik indonesia tentang sistem pendidikan nasional no 20/2003 pasal 1 ayat (1) "pendidikan adalah usaha sadar dan terencana untuk mewujudkan suasana belajar dan proses pembelajaran agar peserta didik secara aktif mengembangkan potensi dirinya untuk memiliki kekuatan spritual keagamaan, pengendalian diri, kepribadian, kecerdasan, akhlak 
mulia serta keterampilan yang diperlukan dirinya, masyarakat bangsa dan negara (Prayitno, 2018).

Pemerintah mengaharapkan makna dan tujuan dari pendidikan dapat tercapai agar nantinya dapat memberikan perkembangan yang baik bagi sumber daya manusia (SDM). Namun untuk mencapai hal tersebut sangat dibutuhkan kerja keras yang baik maka sekolah adalah salah satu bentuk nyata dari kerja pemerintah untuk dapat mencapai tujuan tersebut dengan menciptakan generasi bangsa yang memiliki skils dan soft skils. Dari berbagai kehidupan manusia memiliki hambatan yang menjadikan tujuan tersebut tidak tercapai sehingga mengarah kepada penyipangan perilaku dan bahkan mereka merasa tidak memiliki kemampuan, menjadikan ketidak mampuan mereka sebuah takdir pada kehidupannya.

Manusia adalah makhluk ciptaan tuhan yang di ciptakan sebaik baiknya bentuk pada firman allah "Sesungguhnya, kami telah ciptakan manusia dalam bentuk yang sebaik-baiknya" (QS. At-Tin: 4). Pada surat Al-Israa' ayat 70 Allah SWT berfirman yang artinya, "Dan sesungguhnya telah Kami muliakan anak-anak Adam, Kami angkat mereka di daratan dan di lautan, Kami beri mereka rezeki dari yang baik-baik dan Kami lebihkan dengan kelebihan yang sempurna atas kebanyakan makhluk yang telah Kami ciptakan." (QS. Al-Israa' : 70). Berdasarkan ayat ini kita ketahui bahwa manusia berbeda dengan hewan yang mana kedudukannya manusia lebih mulia di bandingkan dengan mahluk-mahluk lainnya, manusia di berikan akal serta pikiran yang mana akal dan pikiran tersebut menjadikan manusia dapat menjalani kehidupannya dengan baik dan dengan jalan yang baik pula.

Namun dikarenakan adanya nafsu pada manusia maka tak semua manusia menggunakan akal dan pikirannya dengan baik yang mengarah pada kehidupan efektif sehari hari (KES). Fereud mengemukakan ada beberapa hal yang menjadi penunjang perilaku manusia yaitu di dasari oleh id, ego, dan super ego fereud menggambarkan seperti gunung es dimana yang terlihat di permukaan adalah ego yang perinsipnya adalah kenyataan yang terjadi pada kehidupan manusia. Namun hal tersebut hanya sebagian kecil yang telihat. Yang paling terbesar yang terlihat adalah ketidak sadaran yang bagi freud disebut id dan super ego (Wijaya, 2019).

Karena manusia hanya menggunakan id nya saja dan tidak menggunakan super ego sehingga penyimpangan tersebut dilakukan oleh manusia itu dan membuat dirinya semangkin terpuruk dan menjadi pribadi yang tidak baik. Harkat dan martabat manusia adalah hakikat dari kondisi yang ada pada manusia tersebut yang mana harkat martabat berkonsep pada ruh yang mana arti ruh itu sesuatu yang luar biasa yang difitrahkan oleh tuhan fitrah artinya "kebenaran dan keluhuran" (Prayitno, 2020). Dengan terjadinya penyimpangan perilaku manusia yang mengakibatkan rendahnya nilai harkat dan martabat manusia jika semua manusia mengedepankan id nya tanpa menggunaakan super egonya maka tujuan yang awalnya di harapkan dalam pendidikan akan berdampak tidak tercapai. Guru bimbingan dan konseling atau konselor memiliki peran yang sangat penting dalam mengupayakan agar kehidupan manusia yang seperti itu dapat terbantu 
sehingga, menjadikan manusia tersebut meranjak dari kehidupan efektif terganggu KES-T ke kehidupan efektif sehari hari.

\section{METODE}

Penelitian ini dilakukan dengan metode penelitian studi kepustakaan. Penelitian kepustakaan yaitu kegiatan melaksanakan pengumpulan data dan informasi yang berasal dari kumpulan buku dan sumber lain yang selanjutnya ditelaah sehingga menjadi bahan dan data penelitian sebagai bahan dan data penelitian (Zed, 2014). Teknik pengumpulan data yang digunakan adalah studi dokumentasi. Peneliti mengumpulkan bahan dan informasi bersumber buku dan jurnal publikasi (Arikunto dalam Umar \& Nursalim, 2020). Teknik analisi data yang digunakan dalam penelitian ini adalah teknik analisis isi valid (Fajrin \& Christina, 2020; Kusuma \& Pratiwi, 2020).

\section{HASIL PENELITIAN DAN PEMBAHASAN Martabat Manusia}

Manusia diberikan tuhan ruh dengan ruh manusia mampu untuk bergerak dan hidup dan jikaruh tersebut tidak ada pada manusia maka manusia dikatakan meninggal. Teori yang mengatakan bahwa manusia lahir dalam keadaan kosong “ Tabula rasa. Hal ini menjadikan sebuah pemikiran yang mana jika manusia dilahirkan dalam keadaan kosong mungkin saat ini manusia tidak akan mampu mencapai kesuksesan yang dicapainya saat ini.

Dan jika memang konsepnya manusia dapat berbuat berdasarkan apa yang manusia itu lihat atau dalam aspek kognitif maka aspek kognitif itu adalah hal yang terdapat pada manusia tersebut maka secara logikanya manusia tidak kosong. Piaget dalam (Ibda, 2015) menyatakan bahwa cara berfikir anak bukan hanya kurang matang dibandingkan dengan orang dewasa karena kalah pengetahuan, tetapi juga berbeda secara kualitatif. Menurut penelitiannya juga bahwa tahap-tahap perkembangan intelektual individu serta perubahan umur sangat mempengaruhi kemampuan individu mengamati ilmu pengetahuan. Manusia yang berpikir dan dapat berkembang dengan pesat dan menggunakan aspek kognitifnya pada kehidupan yang dirinya jalani adalah bukti nyata bahwa manusia terlahir tidak dalam keadaan kosong.

Kemudian dapat kita contohakan dengan balon jika balon di tiup maka balon tersebut akan mengembang dan didalam balntersebut memiliki isi yang dapat membuat balon tersebut mengembang di dalamnya terdapat angin, bau mulut, air liur. Nah dari pencontohan ini dapat di lihat sesuatu yang dapat berkembang pasti memiliki isi sehingga dapat menjadi berkembang begitu pula dengan manusia yang terlahir. Manusia yang lahir dengan di tiupkannya ruh pastilah memiliki isi pada ruh tersebut sehingga manusia mampu berkembang dan memiliki kompetensi di bidangnya masing masing. Prayitno juga menentang teori yang mengatakan manusia lahir dalam keadaan kosong yang mana konsep dasarnya adalah ada energi kehidupan yang ada pada ruh tersebut sehingga manusia dapat berkembang (Prayitno, 2020). 
Pada surat Al-Israa' ayat 70 Allah SWT berfirman yang artinya, "Dan sesungguhnya telah Kami muliakan anak-anak Adam, Kami angkat mereka di daratan dan di lautan, Kami beri mereka rezeki dari yang baik-baik dan Kami lebihkan dengan kelebihan yang sempurna atas kebanyakan makhluk yang telah Kami ciptakan." (QS. Al-Israa' : 70). Jelas firman allah sebagai bukti bahwa di berikannya ruh bukan dengan dasar yang kosong ruh adalah sesuatu yang mulia. Prayitno mengatakan bahwa terkandung dalam ruh tersebut adalah energi kehidupan sehingga manusia dapat memilih kondisi pada kehidupan meraka dan tak banyak pula dari manusia yang memilih kondisi kehidupan yang menyimpang maka dari kondisi tersebut lah dipahami dengan apa yang di sebut harkat martabat manusia.

Nilai dan hakikat manusia di dalamnya terkandung pengertian bagaimana martabat manusia itu dan nilai-nilai apa saja yang seharusnya dimiliki manusia. Dengan demikian nilai-nilai kemanusiaan universal berkakar dalam martabart manusia (Mudhofir, 1991). Martabat yang berartikan derajat atau pangkat manusia sebagai manusia dengan makna "martabat manusia" mengungkapkan apa yang merupakan keluhuran manusia yang membedakan dari mahklukmahluk lain dibumi. Farnz Magnis dalam (Mudhofir, 1991) pengakuan atas martabat manusia adalah keyakinan dan keterlibatan dasar, sama dengan pengakuan bahwa manusia mempunyai hati nurani dan kewajiban mempertanggung jawabkan perbuatannya. Membicarakan martabat manusia tidak dapat dipakai pembuktian secara matematis -kuatitatif, karena ini menyangkut nilai-nilai. Keluhuran manusia berakar dalam kenyataan bahwa manusia itu memiliki akal dan berbudi. Dengan mempunyai akal budinya berarti bahwa hati dan wawasannya merentangkan dirinya mengatasi segala keterbatasan kearah cakrawala yang tidak terbatas (Mudhofir, 1991).

Point pentingnya pada martabat manusia adalah pengakuan manusia sebagai mahluk yang bernilai bagi dirinya sendiri tidak berarti manusia tersebut hanya mementingkan dirinya sendiri, konselor adalah salah satu manusia yang memiliki peran sosial. Pengakuan masing masing individu tidak sama dengan individualisme. manusia pada hakekatnya adalah mahluk sosial artinya dirinya bergantung pada orang lain. Manusia hanya dapat terjaga dalam martabat dan keutuhannya apabila tuntunan kesetiakawanan, persaudaraan dapat diwujudkan dalam bentuk hormat terhadap nilai dan martabat segenap anggota masyarakat. Permendikbud Nomor 111 Tahun 2014 diterbitkan untuk menjadi acuan baru pelaksanaan tata kelola bimbingan dan konseling mulai dari planning, organizing, staffing, leading dan controlling (Zamroni \& Rahardjo, 2015).

\section{Ciri Keluhuran Dan Kemuliaan Harkat Martabat Manusia}

Terdapat ciri keluhuran manusia di konsepkan sebagai TRIPANCA : pertama, Pancacitra, yaitu pandangan secara positif bahwa manusia adalah makhluk yang beriman dan bertakwa kepada tuhan yang maha esa, diciptakan paling sempurna, paling tinggi derjatnya diantara mahluk yang ada (QS. Al-Israa': 70), sebagai khalifah dimuka bumi, menyandang hak asasi manusia. Kedua, Pancadaya, manusia memiliki potensi yang dapat dikembangkan yaitu; Daya taqwa, daya 
cipta, daya rasa, daya karsa, daya karya. Ketiga, Pancazona, yaitu manusia memiliki daerah kehidupan dalam lima zona yaitu : zona kefitrahan, zona keindividualan, zona kesosialan, zona kesusilaan, zona keberagamaan. (Prayitno, 2020)

\section{Konseling Dan Harkat Martabat Manusia}

Konseling adalah pelayanan bantuan oleh tenaga profesional kepada seseorang atau sekelompok individu untuk perkembangan dan penanganan kehidupan efektif sehari hari terganggu dengan fokus pribadi mandiri yang mampu mengendalikan diri melalui penyelenggaraan berbagai jenis layanan dan kegiatan dalam pendukung dalam proses pembelajaran (Prayitno, 2018). Konseling merupakan salah satu teknik dalam bimbingan, teknik yang dimaksudkan adalah tekni inti atau teknik kunci dikarenakan konseling dapat memberikan perubahan yang mendasar, yaitu mengubah sikap yang mana sikap mendasari perbuatan, pemikiran, pandangan dan perasaan, dan lain sebagainya (Fenti Hikmawati, 2016) Menurut leona E.Tylor dalam (Fenti Hikmawati, 2016) ada lima karakteristik dan termasuk juga kepada prinsip-prinsip konseling yaitu: 1) Konseling bukan hanya sama atau pun sekedar pemberian nasihat kepada orang lain, pada pemberian nasehat ada proses berpikir dan pada proses konseling dilakukan berpikir dan pemecahan masalah dilakukan oleh klien sendiri. 2) setelah diberikannya pelayanan konseling pada siswa maka siswa diharapkan mampu ber-BMB3 (Berpikir, Merasa, Bertindak dan Bertanggung Jawab) (Prayitno, 2018). 3) Konseling mengupayakan perubahan-perubahan yang sifatnya fundamental yang berkenaan dengan pola-pola hidup individu. 4) Konseling menyangkut sikap dari pada perbuatan atau tindakan. 5) Konseling berkenaan dengan penghayatan emosional didbanding pemecahan intelektual

Pada salah satu penelitian menyatakan angka wanita yang terkena kangker payudara yang di sebabkan masa mudanya mengarah pada hubungan yang bersifat negatif yang mana hubungan itu adalah yang mengarah pada hubungan seks pada masa remaja (Audrain et al., 1997). Pada kasus seperti ini adalah bentuk dari prognosis yang ada jika pemberian bimbingan dan koseling di sekolah tidak diterakan bahkan hal yang paling ditakutkan lagi adalah terjangkitnya HIV dan AIDS. Tidak hanya kasus seperti ini yang menjadi pantauan seorang konselor bahkan semua permasalahan yang mungkin terjadi harus menjadi pandangan oleh seorang konselor agar nantinya pemahaman individu/klien menjadi lebih berwawasan dan bertindak dengan mementingkan super egonya tanpa hanya mengedepankan id nya saja.

\section{KESIMPULAN}

Berdasarkan beberapa pemaparan dan penjelasan di atas, maka dapat ditarik sebuah kesimpulan bahwa manusia lahir memang bukan dalam keadaan kosong 
yang mana mausia diberikan ruh yang mulia oleh tuhan yang mana buktinya adalah Al-quran sebagaimana kandungannya manusia diciptakan sebaik baiknya bentuk dan sesempurna mungkin. Harkat martabat manusia di pengaruhi oleh kondisi yang di pilih manusia tersebut namun jika di ambil dari kata keluhuran manusia haruslah melakukan dan menjadi pribadi yang lebih baik. Begitu pula harapan pemerintah yang ingin menjadikan sumberdaya manusia yang lebih baik dengan bentuk kerja dalam ranah pendidikan. Maka konseling adalah upaya yang dapat membantu pencapaian harkat martabat manusia yang baik sehingga menjadi manusia yang penuh dengan keluhuran. Beranjak dari manusia yang tidak dapat hidup sendiri di karenakan manusia adalah makhluk sosial yang membutuhkan orang lain untuk pencapaiannya.

\section{REFERENSI-REFERENSI}

Audrain, J., Schwartz, M. D., Lerman, C., Hughes, C., Peshkin, B. N., \& Biesecker, B. (1997). Psychological distress in women seeking genetic counseling for breast- ovarian cancer risk: The contributions of personality and appraisal. Annals of Behavioral Medicine, 19(4), 370-377. https://doi.org/10.1007/BF02895156

Fajrin, N., \& Christina, E. (2020). Verbal di Sekolah Dasar. Jurnal BK Unesa.

Fenti Hikmawati. (2016). Bimbingan dan Konseling. pt raja grafindo persada.

Ibda, F. (2015). Perkembangan Kognitif: Teori Jean Piaget. Intelektualita, 3(1), 242904.

Kusuma, M. A. Q. M., \& Pratiwi, T. I. (2020). Bermain Peran Untuk Mengurangi Perilaku Bullying. Jurnal BK ..., 610-619.

Lulus, M. U., \& Mochamad, N. (2020). Studi Kepustakaan Tentang Dampak Wabah Covid-19 Terhadap Kegiatan Belajar Mengajar Pada Siswa Sekolah Dasar (SD). Jurnal BK UNESA, Vol 11, No.

Mudhofir, A. (1991). Nilai Martabat dan Hak-Hak Asasi Manusia. Jurnal Filsafat, 23-27.

Prayitno. (2018). Konseling Profesional Yang Berhasil. Raja Grafindo Persada.

Prayitno. (2020). Kehidupan Manusia.

Wijaya, H. (2019). Optimalisasi Superego Dalam Teori Psikoanalisis Sigmud Freud Untuk Pendidikan Karakter (Tia setiadi (ed.)). IRCiSoD.

Zamroni, E., \& Rahardjo, S. (2015). Manajemen Bimbingan Dan Konseling Berbasis Permendikbud Nomor 111 Tahun 2015. Jurnal Konseling Gusjigang, 1(1), 0-11. https://doi.org/10.24176/jkg.v1i1.256

Zed, M. (2014). Metode Penelitian Kepustakaan. Yayasan Obor Indonesia. 